\title{
Expression of CCR2 in Both Resident and Bone Marrow- Derived Microglia Plays a Critical Role in Neuropathic Pain
}

\author{
Ji Zhang, ${ }^{1}$ Xiang Qun Shi, ${ }^{1}$ Stefania Echeverry, ${ }^{1}$ Jeffrey S. Mogil, ${ }^{2}$ Yves De Koninck, ${ }^{1}$ and Serge Rivest ${ }^{3}$ \\ ${ }^{1}$ Unité de Neurobiologie Cellulaire, Centre de Recherche Université Laval Robert-Giffard, Québec, Québec, Canada G1J 2G3, ${ }^{2}$ Department of Psychology and \\ The Alan Edwards Centre for Research on Pain, McGill University, Montreal, Québec, Canada H3A 2T5, and ${ }^{3}$ Laboratoire d'endocrinologie Moléculaire et \\ Oncologique, Centre de Recherche du Centre Hospitalier de l'Université Laval, Québec, Québec, Canada G1V 4G2
}

Neuropathic pain resulting from damage to or dysfunction of peripheral nerves is not well understood and difficult to treat. Although CNS hyperexcitability is a critical component, recent findings challenge the neuron-centric view of neuropathic pain etiology and pathology. Indeed, glial cells were shown to play an active role in the initiation and maintenance of pain hypersensitivity. However, the origins of these cells and the triggers that induce their activation have yet to be elucidated. Here we show that, after peripheral nerve injury induced by a partial ligation on the sciatic nerve, in addition to activation of microglia resident to the CNS, hematogenous macrophage/monocyte infiltrate the spinal cord, proliferate, and differentiate into microglia. Signaling from chemokine monocyte chemoattractant protein-1 (MCP-1, CCL2) to its receptor CCR2 is critical in the spinal microglial activation. Indeed, intrathecal injection of MCP-1 caused activation of microglia in wild-type but not in CCR2-deficient mice. Furthermore, treatment with an MCP-1 neutralizing antibody prevented bone marrow-derived microglia (BMDM) infiltration into the spinal cord after nerve injury. In addition, using selective knock-out of CCR2 in resident microglia or BMDM, we found that, although total CCR2 knock-out mice did not develop microglial activation or mechanical allodynia, CCR2 expression in either resident microglia or BMDM is sufficient for the development of mechanical allodynia. Thus, to effectively relieve neuropathic pain, both CNS resident microglia and blood-borne macrophages need to be targeted. These findings also open the door for a novel therapeutic strategy: to take advantage of the natural ability of bone marrow-derived cells to infiltrate selectively affected CNS regions by using these cells as vehicle for targeted drug delivery to inhibit hypersensitivity and chronic pain.

Key words: nerve injury; leukocyte infiltration; allodynia; spinal cord; chemokine; glial activation

\section{Introduction}

The pathophysiological processes underlying the etiology of neuropathic pain involve molecular and cellular changes in neuronal plasticity and anatomical reorganization at various levels of the peripheral nervous system and CNS (Marx, 2004; Baron, 2006; Campbell and Meyer, 2006). Recent findings have highlighted the active involvement of glial cells in the pathogenesis of nerve injury-induced neuropathic pain and uncover new targets for potential painkilling drugs (Marchand et al., 2005; Tsuda et al., 2005).

Peripheral nerve injury induces activation of spinal microglial cells (Coyle, 1998; Colburn et al., 1999; Fu et al., 1999; Zhang et al., 2003). Activated microglia contribute to neuropathic pain symptomology through the release of molecules that act as direct

\footnotetext{
Received May 9, 2007; revised Sept. 17, 2007; accepted Sept. 18, 2007.

This work was supported by a Canadian Institutes of Health research grant (J.Z.) and a team grant from Neuroscience Canada (Brain Repair program). J.S.M. holds a Canada Research Chair in the Genetics of Pain. Y.D.K is a Chercheur National of the Fonds de la Recherche en Santé du Québec. S.R. holds a Canada Research Chair in Neuroimmunology. We thank Martine Lessard for technical assistance for the generation of the chimeric mice.

Correspondence should be addressed to Dr. JiZhang at her present address: The Alan Edwards Centre for Research on Pain, McGill University, 740, Dr. Penfield Avenue, Suite 3200C, Montreal, Québec, Canada H3A 2B2. E-mail: ji.zhang@mcgill.ca.

X. Q. Shi's and S. Echeverry's present address: The Alan Edwards Centre for Research on Pain, McGill University, Montreal, Québec, Canada H3A 2B2.

D0I:10.1523/JNEUROSCI.3016-07.2007

Copyright $\odot 2007$ Society for Neuroscience $\quad 0270-6474 / 07 / 2712396-11 \$ 15.00 / 0$
}

modulators of neuronal excitability (Tsuda et al., 2003; Coull et al., 2005). A major question remains unanswered: where do these activated microglial cells come from and is there a specific population involved in pain? The normal CNS is characterized by two major monocyte-related populations: highly ramified CNS resident microglia and hematopoietic perivascular macrophages (Raivich and Banati, 2004). The renewal of microglia in adulthood occurs not only through the proliferation of preexisting cells but also through the recruitment of precursors that derive from bone marrow (BM), because the perivascular macrophages replenished by circulating monocyte could migrate through basal membrane into the CNS parenchyma, a process enhanced in different forms of inflammatory neuropathology (Streit et al., 1989; Lawson et al., 1992; Priller et al., 2001; Sweitzer et al., 2002). The relative contribution of resident and invading microglia to the pathogenesis may vary depending on the setting and severity of the injury, as is evidenced by the different dynamics of BMderived cell accumulation (Furuya et al., 2003; Priller et al., 2006; Solomon et al., 2006; Denker et al., 2007). An understanding of the distinct contribution of cells of the monocytic lineage in injury-induced neuropathic pain is important for directing the search for novel therapeutic targets.

Whenever neurons are injured, microglia become activated, both at the primary lesion sites and remote from primary damage, at sites where the damaged neurons project (Kreutzberg, 
1996). Thus, microglial activation is likely to be controlled by endangered neurons. The identity of the molecules involved in neuron-microglia signaling in different injury conditions remains an active subject of investigation. Chemokines and their receptors constitute an elaborate signaling system that plays an important role in cell-to-cell communication not only in the peripheral immune system but also in the CNS (Ransohoff and Tani, 1998; Ambrosini and Aloisi, 2004; Moser et al., 2004; Rot and von Andrian, 2004). Monocyte chemoattractant protein-1 (MCP-1), also named CCL2, is a member of the CC family chemokine that specifically attracts and activates monocytes to the sites of inflammation (Leonard et al., 1991). Absent in normal CNS, MCP-1 was found to be induced in facial nucleus neurons by facial nerve transection (Flugel et al., 2001), in sympathetic ganglion neurons after postganglionic axotomy (Schreiber et al., 2001), and in DRG sensory neurons and spinal cord motor neurons by chronic constriction of the sciatic nerve (Tanaka et al., 2004; Zhang and De Koninck, 2006). CCR2, the receptor for MCP-1, is expressed selectively on cells of monocyte/macrophage lineage in periphery (Rebenko-Moll et al., 2006) and can be induced in spinal microglia by peripheral nerve injury (Abbadie et al., 2003). We also demonstrated that, both spatially and temporally, MCP-1 induction is closely correlated with the subsequent surrounding microglial activation (Zhang and De Koninck, 2006). We predicted that the induced neuronal MCP-1 could be the signaling molecule that activates resident spinal microglial and/or attracts peripheral macrophages into the spinal cord. Also, it could contribute to peripheral sensitization by attracting macrophages to the injured nerve and DRG. It has been demonstrated that mice lacking the CCR2 [CCR2 knock-out (KO)] had impaired nociceptive response typically associated with neuropathy (Abbadie et al., 2003), but the exact contribution of CCR2 in resident and bone marrow-derived microglia has yet to be clearly defined.

In the present study, we identified the origins of activated microglia by using chimeric mice in which their bone marrow was replaced by one that expresses green fluorescent protein (GFP). We show that, after peripheral nerve injury, in addition to activation of microglia resident to the spinal cord, blood-borne macrophages have the ability to infiltrate the spinal cord, proliferate, and differentiate into activated microglia. We also showed that infiltration of peripheral macrophages into the spinal cord after nerve injury involves direct MCP-1/CCR2 signaling from the CNS to the periphery. The fact that both resident microglia and bone marrow-derived macrophages participate in the modulation of central sensitization in neuropathic pain indicates that inhibition of either resident microglia or of peripheral macrophages may not be an efficient approach to relieve neuropathic pain. Both need to be targeted.

\section{Materials and Methods}

\section{Animals}

Adult (7- to 12-week-old) male C57BL/6 mice were purchased from The Jackson Laboratory (Bar Harbor, ME). Hemizygous transgenic mice expressing GFP under the control of the chicken $\beta$-actin promoter and cytomegalovirus enhancer and CCR2 knock-out mice were initially obtained from the same vendor. Local colonies of GFP and CCR2KO mice were then established and maintained on a C57BL/6 background, respectively. Mice were housed four per cage after weaning in a temperatureand humidity-controlled vivarium, on a 14/10 h light/dark cycle (lights on at 6:00 A.M. and off at 8:00 P.M.), with access to rodent chow and water ad libitum. Behavioral experiments were conducted from 8:00 A.M. to 4:00 P.M. All protocols were conducted according to the Cana- dian Council on Animal Care guidelines, as administrated by the Laval University Animal Welfare Committee.

\section{Generation of bone marrow-chimeric mice}

Recipient mice were exposed to 10-gray total-body irradiation using a cobalt-60 source (Theratron-780 model; MDS Nordion, Ottawa, Ontario, Canada). A few hours later, the animals were injected via tail vein with $\sim 5 \times 10^{6}$ bone marrow cells freshly collected from donor mice. The cells were aseptically harvested by flushing femurs with Dulbecco's PBS (DPBS) containing $2 \%$ fetal bovine serum. The samples were combined, filtered through a $40 \mu \mathrm{m}$ nylon mesh, centrifuged, and passed through a 25 gauge needle. Recovered cells were resuspended in DPBS at a concentration of $5 \times 10^{6}$ vial nucleated cells per $200 \mu$ l. Irradiated mice transplanted with this suspension were housed in autoclaved cages and treated with antibiotics $(0.2 \mathrm{mg}$ of trimethoprim and $1 \mathrm{mg}$ of sulfamethoxazole per milliliter of drinking water given for $7 \mathrm{~d}$ before and 2 weeks after irradiation). Animals were subjected to partial sciatic nerve ligation 3-5 months after transplantation.

GFP chimeric mice. GFP-positive $\left(\mathrm{GFP}^{+}\right)$transgenic mice were used as $\mathrm{BM}$ donors. $\mathrm{C} 57 \mathrm{BL} / 6$ mice were irradiated and transplanted with $\mathrm{GFP}^{+}$ cells via the tail vein.

Central CCR2KO chimeric mice. CCR2KO mice were used as BM recipients. $\mathrm{GFP}^{+}$transgenic BM cells were transplanted into irradiated CCR2KO mice.

Peripheral CCR2KO chimeric mice. GFP ${ }^{+}$transgenic mice were used as $\mathrm{BM}$ recipients. Bone marrow cells collected from CCR2KO mice were transplanted into irradiated $\mathrm{GFP}^{+}$transgenic mice.

The presence of $\mathrm{GFP}^{+}$donor-derived cells in the peripheral circulation of transplant recipients in each chimeric group was analyzed 8 weeks after transplantation by fluorescence-activated cell sorting. The GFP chimeric mice and central CCR2 $\mathrm{KO}$ chimeric mice used in the protocol had all $>80 \%(83.6 \pm 5.03 \% ; n=50)$ of $\mathrm{GFP}^{+}$peripheral blood leukocytes, and peripheral CCR $2 \mathrm{KO}$ chimeric mice had only $1.53 \pm 0.03 \%(n=10)$ $\mathrm{GFP}^{+}$cells in the blood.

Irradiation bone marrow chimeric mouse generation is currently widely used to distinguish blood-derived and CNS resident microglia. To exclude the possibility that the cell recruitment is an artifact of irradiation or bone marrow transplantation, some additional approaches, such as intrasplenic injection of 6-carboxylfluorescein diacetate, a long-lasting intracellular fluorescent tracer, and using unirradiated parabionts with surgically anatomosed vasculature have been reported. As seen in GFP bone marrow chimeras, monitoring invasion of blood-derived cells in the absence of previous irradiation and bone marrow transplantation clearly revealed that recruitment of leukocytes across the blood-brain barrier contributes to the accumulation of ionizing calcium-binding adaptor molecule-positive $\left(\mathrm{Iba}-1^{+}\right.$) cells within the CNS parenchyma in different pathological conditions (Bechmann et al., 2005; Massengale et al., 2005). More importantly, irradiation does not affect the ability of resident cells to proliferate after spinal cord injury (Horky et al., 2006).

\section{Nerve injury model and behavioral studies}

Partial sciatic nerve ligation was conducted according to the method of Seltzer et al. (1990) as adapted to mice (Malmberg and Basbaum, 1998). Briefly, under isoflurane anesthesia and aseptic conditions, the left sciatic nerve was exposed at high-thigh level. The dorsum of the nerve was carefully freed from surrounding connective tissues at a site near the trochanter. A 8-0 suture was inserted into the nerve with a $3 / 8$ curved, reversed-cutting mini-needle (Tyco Health Care, Mississauga, Ontario, Canada) and tightly ligated so that the dorsal one-third to one-half of the nerve thickness was trapped in the ligature. The wound was then closed with two muscle sutures (4-0) and two to three skin sutures (4-0). In sham-operated mice, the nerve was exposed and left intact. The wound was closed as in injured mice.

All animals were assessed for mechanical sensitivity before surgery and from days 2-3 after injury until they were killed for histological studies. The investigator was totally blinded to the treatments the mice received. Paw-withdrawal threshold was measured with calibrated von Frey fibers using the up-down method (Chaplan et al., 1994), as described previously (Mogil et al., 1999). Mice were placed on a metal mesh floor with 
small Plexiglas cubicles $(9 \times 5 \times 5 \mathrm{~cm}$ high $)$, and a set of eight calibrated von Frey fibers (ranging from 0.008 to $1.40 \mathrm{~g}$ of force) were applied to the plantar surface of the hindpaw until they bent. The threshold force required to elicit withdrawal of the paw (median 50\% paw withdrawal) was determined on two tests separated by at least $1 \mathrm{~h}$. All animals were habituated for at least $2 \mathrm{~h}$ to their individual Plexiglas observation chamber before testing. Baseline data (day 0 ) was obtained by averaging measurements made $1-2 \mathrm{~d}$ before surgery.

\section{Intrathecal injections}

In a subset of animals, recombinant mouse (rm) MCP-1 (R \& D Systems, Minneapolis, $\mathrm{MN}$ ) or neutralizing antibody against mouse MCP-1 (R \& D Systems) were injected by intrathecal punctions at the level of L5-L6 under isoflurane anesthesia. The rmMCP-1 was delivered every $2 \mathrm{~d}(2 \mu \mathrm{g}$ in $10 \mu \mathrm{l}$ of saline per injection) in adult naive CCR2KO and wild-type $(\mathrm{C} 57 \mathrm{BL} / 6)$ mice, and the animals were killed at day 6 after the first injection and processed for immunohistochemistry as described below. The MCP-1 neutralizing antibody was delivered in adult GFP chimeric mice with nerve injury. Starting from the day of surgery, mice received an injection of the antibody every $2 \mathrm{~d}$ until day 13 after injury $(4 \mu \mathrm{g}$ in $10 \mu \mathrm{l}$ of saline per injection). Animals were then perfused for visualization of GFP cell infiltration at day 14 after injury. Mice in the control groups received intrathecal injections of an equal volume of saline.

\section{Immunohistochemistry}

In wild-type (C57BL/6) and GFP chimeric mice, bromodeoxyuridine (BrdU) (50 mg/kg; Sigma, St. Louis, MO) was injected intraperitoneally at day 3 after injury, and animals were killed $2 \mathrm{~h}, 4 \mathrm{~d}, 11 \mathrm{~d}$, and $27 \mathrm{~d}$ after injection. To collect the spinal cord tissues of all animals used in the current study, mice were deeply anesthetized via an intraperitoneal injection of a mixture of ketamine hydrochloride and xylazine and then rapidly perfused transcardially with $0.9 \%$ saline, followed by $4 \%$ paraformaldehyde in sodium phosphate buffer. Lumbar spinal cords were removed and postfixed overnight. Lumbar spinal cord (L4-L5 segments) were cut into $30 \mu \mathrm{m}$ sections, then collected in a cold cryoprotectant solution ( $0.05 \mathrm{~m}$ sodium phosphate buffer, $\mathrm{pH} 7.3,30 \%$ ethylene glycol, and $20 \%$ glycerol), and stored at $-20^{\circ} \mathrm{C}$.

To allow the detection for BrdU-labeled cells, free-floating sections were pretreated with $50 \%$ formamide in $2 \times$ SSC for $2 \mathrm{~h}$ at $65^{\circ} \mathrm{C}$, followed by $15 \mathrm{~min}$ in $2 \times \mathrm{SSC}$ at room temperature, $30 \mathrm{~min}$ in $2 \mathrm{~N} \mathrm{HCl}$ at $37^{\circ} \mathrm{C}, 10$ min in $0.1 \mathrm{M}$ borate buffer at room temperature. Nonspecific labeling was blocked with TBS plus $0.25 \%$ Triton X-100, 1\% BSA, and 3\% normal goat serum for $1 \mathrm{~h}$. A polyclonal goat anti-rat antibody against BrdU (1:250; Accurate Chemicals, Westbury, NY) was incubated with tissue sections for $48 \mathrm{~h}$ at $4^{\circ} \mathrm{C}$. After primary antibody incubation, sections were rinsed in TBS and incubated in Alexa 488-conjugated goat anti-rat IgG (in TBS containing $0.25 \%$ Triton X-100, 1\% BSA, and 3\% normal goat serum, 1:250; Invitrogen, Carlsbad, CA) for $1 \mathrm{~h}$. After rinses in TBS, sections were mounted onto slides and coverslipped with Vectashield mounting medium (Vector Laboratories, Burlingame, CA).

Regular immunofluorescent staining was performed to identify the phenotypes of infiltrated BM cells and spinal microglia reaction to the peripheral nerve injury. Free-floating sections were first treated in TBS containing 3\% normal serum, $1 \%$ BSA, and 0.25 Triton X-100 for $1 \mathrm{~h}$ at room temperature and then $30 \mu \mathrm{m}$ spinal cord sections were incubated overnight at $4^{\circ} \mathrm{C}$ with antibodies listed below: mouse anti-neuronspecific nuclear protein (NeuN) monoclonal antibody (for neurons, 1:1000; Chemicon, Temecula, CA), rabbit anti-Iba-1 polyclonal antibody (for microglia and macrophages, 1:1000; Wako Chemicals, Richmond, VA), rabbit anti-glial fibrillary acid protein (GFAP) polyclonal antibody (for astrocytes, 1:1000; DakoCytomation, Carpinteria, CA), rabbit anti-NG2 polyclonal antibody (chondroitin sulfate proteoglycan, for oligodendrocyte progenitors, 1:250; Chemicon), and monoclonal rat anti-CD31 (for endothelial cells, 1:1000; BD Biosciences PharMingen, San Diego, CA), respectively, followed by a $60 \mathrm{~min}$ incubation at room temperature in fluorochrome-conjugated goat secondary antibody. The sections were then mounted onto SuperFrost slides (Fisher Scientific, Nepean, Ontario, Canada) and coverslipped with Vectashield mounting medium (Vector Laboratories). In some cases, to better identify the an- atomical distribution of infiltrated cells, additional immunostaining was performed using a polyclonal antibody against GFP (1:1000; Invitrogen), revealed by a DAB-based enzymatic method; the tissue was then counterstained with thionin to identify the parenchyma.

\section{Image analysis}

Images were acquired either using an Olympus Optical (Tokyo, Japan) microscope (AX-70) equipped with a Spot Camera or a Zeiss (Oberkochen, Germany) LSM 510 confocal laser-scanning microscope. Colocalization was ensured with confocal $\mathrm{Z}$ stacks at $1 \mu \mathrm{m}$ intervals and visualization in three-dimensional orthogonal planes. Quantitative analysis of the immunofluorescence intensity was performed on images digitized using a constant set of parameters (exposure time, gain, and postimage processing) with special care to avoid signal saturation. We measured the intensity of Iba- 1 immunofluorescence as the average pixel intensity within a rectangle $(197 \times 533$ pixels $)$ on the dorsal horn $(\mathrm{DH})$ (lamina I-IV) and a rectangle $(224 \times 294$ pixels $)$ on the ventral horn (VH) (lamina IX), on both sides relative to the side of injury (MetaMorph, version 6.2r6; Universal Imaging, Downingtown, PA). GFP ${ }^{+}$ cells, $\mathrm{BrdU}^{+}$cells, and $\mathrm{Iba}-1^{+}$microglial cells were counted by two independent investigators in four different regions of interest [ipsilateral $\mathrm{DH}(\mathrm{DHi})$, contralateral $\mathrm{DH}(\mathrm{DHc}), \mathrm{VHi}$, and $\mathrm{VHc}]$. Only ramified $\mathrm{GFP}^{+} / \mathrm{Iba}-1^{+}$cells within parenchymal gray matter were included.

\section{Statistics}

All data are presented as means \pm SEM. Statistical analysis was based on the following: (1) repeated-measures ANOVA followed by Dunnett's case-comparison post hoc test for behavioral analyses; (2) paired $t$ test for the difference in intensity of Iba- 1 signal between ipsilateral and contralateral side in the $\mathrm{DH}$ and $\mathrm{VH}$, respectively; (3) unpaired $t$ test for the difference in intensity of Iba-1 signal between groups (peripheral/central CCR2KO DHi vs GFP chimera DHi; peripheral/central CCR2KO VHi vs GFP chimera VHi).

\section{Results \\ Infiltration of bone marrow-derived cells into spinal cord after peripheral nerve injury}

To identify the origins of the activated microglia observed in the spinal cord after peripheral nerve injury, we transplanted GFPexpressing bone marrow stem cells into irradiated C57BL/6 mice (GFP chimeric mice). We found that, in naive animals, $\mathrm{GFP}^{+}$ cells were virtually absent in the spinal cord parenchyma, and the few $\mathrm{GFP}^{+}$cells found in the spinal cord had an elongated shape and were restricted to blood vessels (Fig. 1A). We then subjected the mice to either a sham surgery of the thigh or a partial sciatic nerve ligation injury. In sham-operated mice, the number of GFP cells was slightly higher in the spinal cord, but there was no significant difference between the ipsilateral and contralateral sides (Fig. 1A). In contrast, many ramified GFP-expressing cells were present in the DHi and VHi of the L4-L5 spinal cord after nerve injury (Fig. 1A). The different morphologies of $\mathrm{GFP}^{+}$cells are depicted in Figure $1 B-D$. The results were confirmed by immunolabeling with a polyclonal antibody against GFP for infiltrated cells. Counterstaining with thionin helped better identify the anatomical localization of $\mathrm{GFP}^{+}$cells (Fig. $1 \mathrm{E}-\mathrm{H}$ ).

To identify the phenotype of these ramified $\mathrm{GFP}^{+}$donor cells, we used an antibody directed against Iba-1 to label microglia. Confocal microscope analysis on $x, y$, and $z$ orthogonal planes provided direct evidence that virtually all $\mathrm{GFP}^{+}$cells present within the spinal cord parenchyma were Iba-1-positive ramified cells (Fig. 2A-C). Double immunolabeling of GFP with other cellular markers, NeuN for neurons, GFAP for astrocytes, NG2 for oligodendrocyte progenitors, and CD31 for endothelial cells, were also conducted. No evidence of GFP colocalization with the above markers has been observed (Fig. 2D).

To determine the temporal profile of BM-derived cell infiltra- 
A

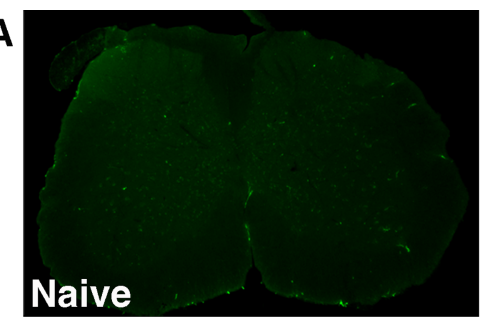

B

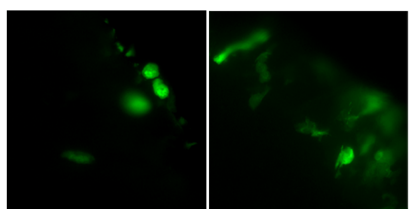

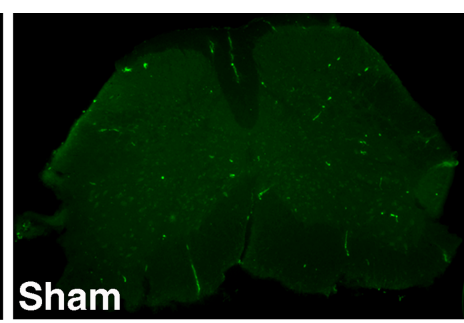
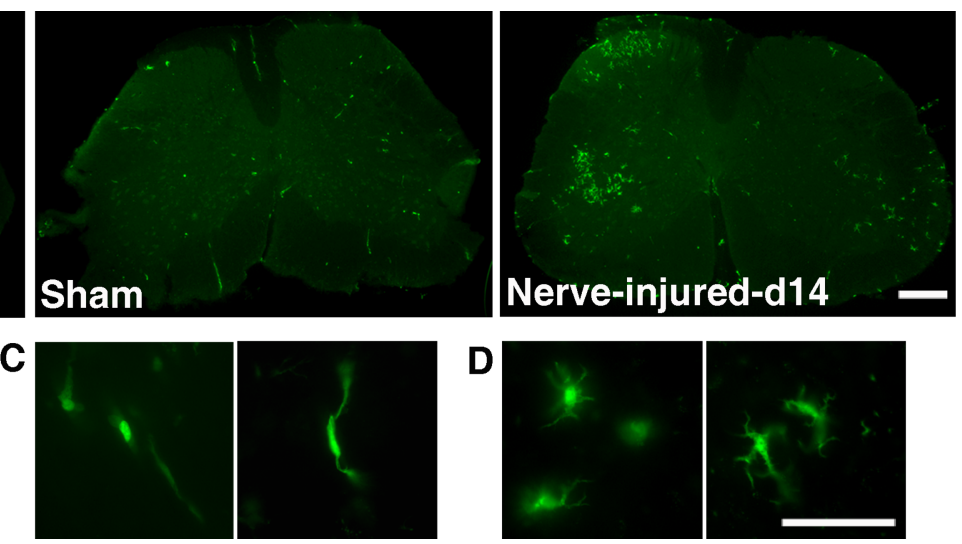

$\mathrm{D}$

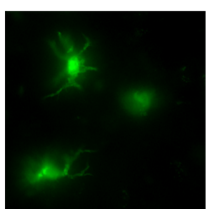

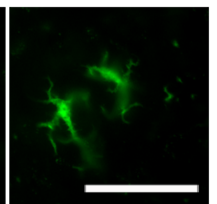

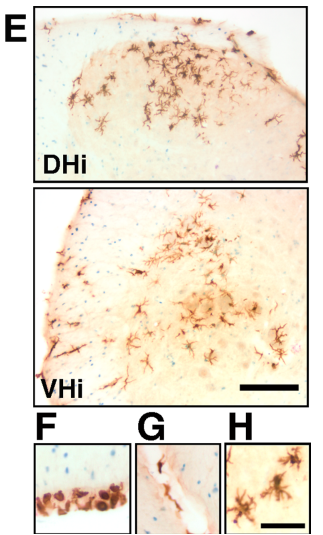

Figure 1. Infiltration of bone marrow-derived cells into the spinal cord after sciatic nerve injury. $\boldsymbol{A}, \mathrm{BM}$-derived cells in the lumbar spinal cord of naive, sham-operated and sciatic nerve-injured mice. No ramified GFP ${ }^{+}$cells were found in the spinal parenchyma of non-injured animals. In contrast, GFP ${ }^{+}$cell infiltration was remarkable in injured animals, which was restricted in the ipsilateral side of the injury (scale bar, $1 \mathrm{~mm}$ ). $\boldsymbol{B}-\boldsymbol{D}$, Meningeal GFP ${ }^{+}$cells had a round shape $(\boldsymbol{B})$, they were elongated when associated with blood vessels $(\boldsymbol{C})$, and ramified within the parenchyma $(\boldsymbol{D})$ (scale bar, $100 \mu \mathrm{m})$. $\boldsymbol{E}-\boldsymbol{H}$, Immunolabeling of infiltrated cells with a polyclonal antibody against GFP, counterstained by thionin, revealed their anatomical localization in DHi and VHi (day 14 after injury) $(\boldsymbol{E})$ and different cellular shapes depending on the distribution in the meninges $(\boldsymbol{F})$, within vessels $(\boldsymbol{G})$, and parenchyma $(\boldsymbol{H})(\mathrm{scale}$ bar, $50 \mu \mathrm{m})$.

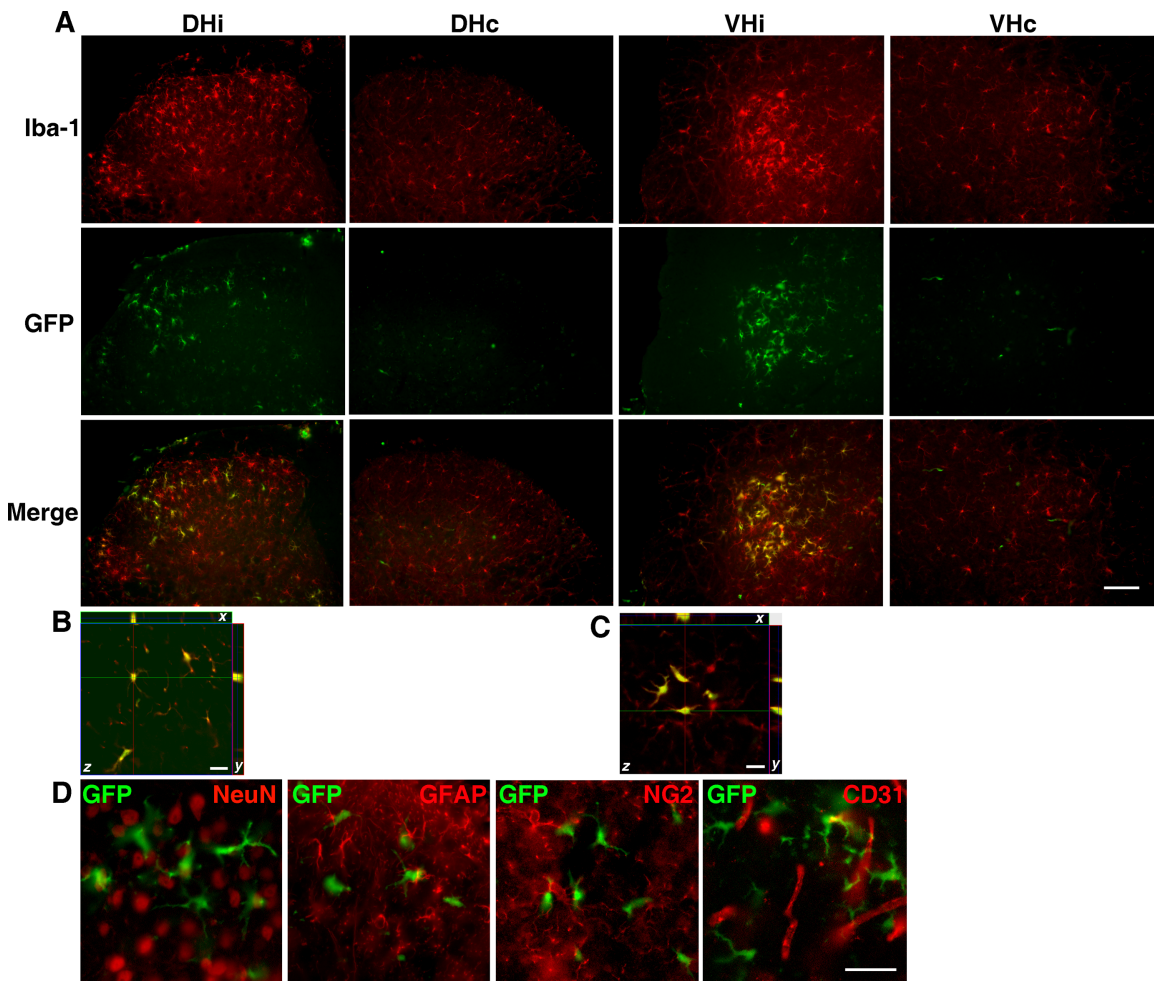

Figure 2. Phenotype identification of infiltrated BM-derived cells in the lumbar spinal cord. $A$, Intense lba-1 labeling was found in activated microglia in the ipsilateral side spinal cord (DH/VH), whereas Iba-1 immunofluorescence was weak (red) in the contralateral DH/VH. Ramified GFP ${ }^{+}$cells (green) overlapped with the lba- 1 immunoreactive signal in the ipsilateral DH/VH. Almost all ramified GFP ${ }^{+}$cells within the parenchyma were lba- $1^{+}$(merge) (scale bar, $200 \mu \mathrm{m}$ ), which was confirmed by confocal microscopic analysis in the $x, y$, and $z$ orthogonal planes in DH (B) and VH (C) (scale bar, $10 \mu \mathrm{m})$. D, No colocalization of GFP with other cellular markers (NeuN, GFAP, NG2, and CD31) was observed in the lumbar spinal cord dorsal horn $14 \mathrm{~d}$ after injury (scale bar, $100 \mu \mathrm{m}$ ).

tion and its relationship with CNS resident microglia, we quantified the number of ramified GFP-expressing cells among all Iba-1 immunoreactive microglia in four different regions of interest: DHi, DHc, VHi, and VHc. Three days after nerve lesion, an average of $9 \%$ of microglia in the DHi and $22 \%$ in the VHi expressed GFP $\left(\mathrm{DHi}, 3.6 \pm 0.6 \mathrm{GFP}^{+}\right.$cells; VHi, $8.0 \pm 2.3 \mathrm{GFP}^{+}$ cells). At days 7-14 after injury, 25-27 and $41-42 \%$ of microglia in the $\mathrm{DHi}$ and the $\mathrm{VHi}$ were found to be $\mathrm{GFP}^{+}$, respectively. One month after the injury, the number of $\mathrm{GFP}^{+}$cells decreased to 6 and $16 \%$ in the DHi and the VHi, respectively (Fig. 3). The time course of the increase in $\mathrm{GFP}^{+}$cell number in the lumbar spinal cord paralleled that of microglial activation (Fig. 3).

\section{Proliferation and differentiation of bone marrow-derived cells within the spinal cord parenchyma}

We then assessed the plasticity of these infiltrating cells by determining their capacity to proliferate and differentiate into microglia. Animals were injected with BrdU $3 \mathrm{~d}$ after injury and perfused at different time points afterward (days 3-30). Immunofluorescence staining of incorporated BrdU revealed that peripheral nerve injury induced cell proliferation in the spinal cord, ipsilateral to the side of nerve injury, from days 3 to 14 (Fig. 4A). Nerve injury increased the number of $\mathrm{BrdU}^{+}$cells in both irradiated GFP chimeric mice and non-irradiated control C57BL/6 mice equally (data not shown). Double immunolabeling of BrdU with GFP demonstrated that both resident cells (red arrow) and BM-derived hematopoietic cells (yellow arrow) proliferated within the spinal cord parenchyma (Fig. 4B), in which 19.7 and $22.3 \%$ of $\mathrm{BrdU}^{+}$cells derived from peripheral macrophages in the $\mathrm{DHi}$ and the VHi, respectively (Fig. 4C).

We next analyzed morphological changes in these infiltrated $\mathrm{GFP}^{+}$cells. Although they had a round shape when lining the meninges, they developed broad and short processes once they infiltrated the parenchyma (day 3). At later time points (days 7-30), most GFP ${ }^{+}$cells were highly ramified microglial cells with relatively small cell bodies, resembling their resident counterparts (Fig. 4C). Thus, newly recruited hematogenous macrophages invaded the spinal cord parenchyma proliferated and differentiated gradually into highly ramified microglia. 
Role of CCR2 in mediating microglial chemotaxis in the spinal cord

To test the hypothesis that CCR2 is critical in resident microglial activation and peripheral macrophage infiltration, we first compared Iba-1 immunofluorescence in sections of L4-L5 spinal cord taken from wild-type (C57BL/6) and CCR2-deficient (CCR2KO) mice. Although nerve injury induced a striking increase of Iba-1 immunoreactivity in the DHi and VHi of wildtype (C57BL/6) mice at day 14 after nerve injury, such an increase was almost completely abolished in CCR2KO mice (Fig. 5A,B). This finding suggests that CCR2 expression is necessary for both activation of resident microglia and chemotaxis of BM-derived cells after peripheral nerve injury.

Chemotaxis of BM-derived cells may, however, occur secondarily to activation of resident microglia expressing CCR2. To test for this possibility, we next generated two other groups of chimeric mice by transplanting BM cells collected from GFP transgenic mice into irradiated CCR2KO mice (central CCR2KO chimera) and by transplanting CCR2KO bone marrow cells into irradiated GFP transgenic mice (peripheral CCR2KO chimera). The expression pattern of Iba-1 was similar in wild-type non-irradiated mice and GFP chimeric mice, showing that irradiation and bone marrow cell transplantation did not modify the ability of resident microglia and BM-derived cells to respond to nerve injury (Fig. 5A). We quantified the mean intensity of Iba- 1 immunoreactive signal in defined regions of the dorsal and ventral horns, in which microglial activation was considered to be the most prominent. All groups of chimeric mice exhibited significant differences in Iba-1 staining between ipsilateral and contralateral sides after injury (Fig. $5 B$ ). In addition, the Iba- 1 signal was significantly lower on the side ipsilateral to the injury in both groups of CCR2KO chimeric mice when compared with the ipsilateral side in GFP chimeric mice (Fig. 5A, $B$ ).

The same result was obtained by counting Iba- $1^{+}$cells (Table 1). When CCR2 was absent in the periphery, the decrease in Iba- ${ }^{+}$cell number (Table 1, $A$ minus $C$ ) corresponded to that of infiltrated cells in the GFP chimeric mice (Table 1, B). Similarly, when CCR2 was absent in the CNS, the difference in Iba- $1^{+}$cell number between central CCR2 KO and total CCR2KO (Table 1, D minus $E$ ) corresponded to the number of infiltrated cells in the GFP chimeric mice (Table 1, B). The loss in Iba-1 staining in each condition thus reflected the contribution of activated resident microglia and bone marrow-derived infiltrated macrophages, respectively. The results thus indicate that CCR2 expression is not only necessary for the activation of resident microglia but is also directly responsible for recruitment of BM-derived cells to the CNS.

MCP-1 is the trigger for macrophage infiltration and activation of resident microglia via its cognate receptor CCR2 To identify the ligand that activated the CCR2 receptor, we injected intrathecally rmMCP-1 in wild-type and in CCR2KO mice. Exogenous MCP-1 induced an increase in the size of microglial cell bodies as shown by Iba-1 immunostaining in intact wild-type mice, and these changes were abolished in CCR2deficient mice (Fig. 6A). In addition, we injected intrathecally an antibody against mouse MCP-1 in GFP chimeric mice having nerve injury to verify whether neutralization of MCP-1 could prevent peripheral macrophage infiltration. In four of seven animals, $\mathrm{GFP}^{+}$cell infiltration was completely abolished. Overall, the number of ramified $\mathrm{GFP}^{+}$cells was significantly reduced in mice injected with the MCP-1 neutralizing antibody compared with mice that received control saline injection (Fig. $6 B, C$ ).

\section{CCR2 in either CNS microglia or in bone marrow-derived macrophages is sufficient for the development of mechanical allodynia}

Development of mechanical hypersensitivity (allodynia) is a clinically relevant characteristic of nerve injury. To address the relationship between mechanical allodynia and the chemotaxis of resident and BM-derived microglia, we measured pawwithdrawal threshold to mechanical stimuli in all animals before and after injury. Before nerve injury, the withdrawal threshold was not affected by the CCR 2 gene deletion nor by the irradiation and bone marrow cell transplantation (Fig. 7). Wild-type C57BL/6 mice showed a robust decrease in withdrawal threshold from $0.35 \pm 0.01 \mathrm{~g}$ before surgery to $0.09 \pm 0.01 \mathrm{~g}(p<0.01)$ at day 3 after surgery and maintained this hypersensitivity to the end of the testing period (day 14) (Fig. 7A). Mechanical allodynia was significantly attenuated in CCR2KO mice (Fig. $7 B$ ) and in GFP chimeric mice treated with MCP-1 antibody (58 $\pm 3.8 \%$ reduction compared with saline treated mice at day 12 after injury; $n=7$ per group), indicating that MCP-1/CCR2 signaling plays a critical role in the development of the hypersensitivity. In contrast, however, neither selective peripheral CCR2KO nor selective central CCR2 KO mice had their allodynia significantly attenuated (Fig. $7 D, E$ ). This result indicates that expression of CCR2 in either resident or BM-derived cells is sufficient for the 
development of mechanical allodynia after peripheral nerve injury.

\section{Discussion}

Here we demonstrate that BM-derived macrophages have the ability to infiltrate the spinal parenchyma after peripheral nerve injury. Interestingly, in contrast to spinal cord injury, the blood-spinal cord barrier (BSCB) remains physically intact after peripheral nerve injury, yet our results show that chemotaxis occurs across the BSCB. These infiltrated macrophages proliferate and differentiate into microglia and, together with their resident counterparts, contribute to CNS microgliosis in response to peripheral nerve injury. We reported previously that MCP-1, the endogenous ligand for CCR2 receptors, is produced by injured neurons (Zhang and De Koninck, 2006). In the current study, we demonstrated that exogenous MCP-1 could induce spinal microglial activation and this activation is lost in CCR2KO mice. In addition, neutralization of MCP-1 prevented peripheral macrophage infiltration after nerve injury. Together, these findings imply a neuron-to-microglia and neuron-to-macrophage signaling mechanism underlying the central component of neuropathic pain pathogenesis. The fact that both resident and $\mathrm{BM}$-derived microglia participate in the development of the pathology has direct clinical importance. Inhibiting either resident microglia or BM-derived macrophages may not be an effective approach to relieve neuropathic pain.

Recruitment of circulating leukocytes into the CNS in normal physiological conditions and in pathological states supports the essential functions of immunosurveillance and host

Figure 4. Proliferation and differentiation of infiltrated bone marrow-derived cells. $A$, Representative BrdU staining in the lumbar spinal cord of GFP chimeric mice (14 d after injury, $11 \mathrm{~d}$ after BrdU injection). Note the increase of BrdU-positive cells in the lumbar spinal cord, ipsilateral to the injury (scale bar, $1 \mathrm{~mm}$ ). B, Z-sectioned scan with confocal microscope (Zeiss LSM 510) through the extent of BrdUpositive nucleus to verify the double labeling with $\mathrm{GFP}^{+}$cells. BrdU and GFP colocalization showing cell proliferation within BM-derived microglia (yellow arrow); BrdU single labeling showing cell proliferation in resident cells (red arrowhead) (scale bar, $20 \mu \mathrm{m}$ ). C, Quantitative analysis of the number of $\mathrm{GFP}^{+} / \mathrm{BrdU}^{+}$cells over total $\mathrm{BrdU}^{+}$ cells ( $14 \mathrm{~d}$ after injury, $n=3,3-4$ sections per animal, total of 277 $\mathrm{BrdU}^{+}$cells in DH and $201 \mathrm{BrdU}^{+}$cells in VH were counted) indicating that, $14 \mathrm{~d}$ after injury, when microglial activation on the ipsilateral side reached its peak, $\sim 20 \%$ of proliferating cells derived from peripheral macrophages (data are presented as mean \pm SEM). $\boldsymbol{D}$, Photomicrographs showing the morphological plasticity of BM-derived cells over time. Until they were recruited into the parenchyma, they were round/ oval shaped on the endothelium; shortly after their penetration (day 3 after injury), BM-derived GFP ${ }^{+}$cells displayed few short branches with a large cell body; during days 7-14, they developed into ramified cells; $30 \mathrm{~d}$ after injury, these infiltrated BM-derived cells differentiated into highly ramified microglia (scale bar, $100 \mu \mathrm{m}$ ).

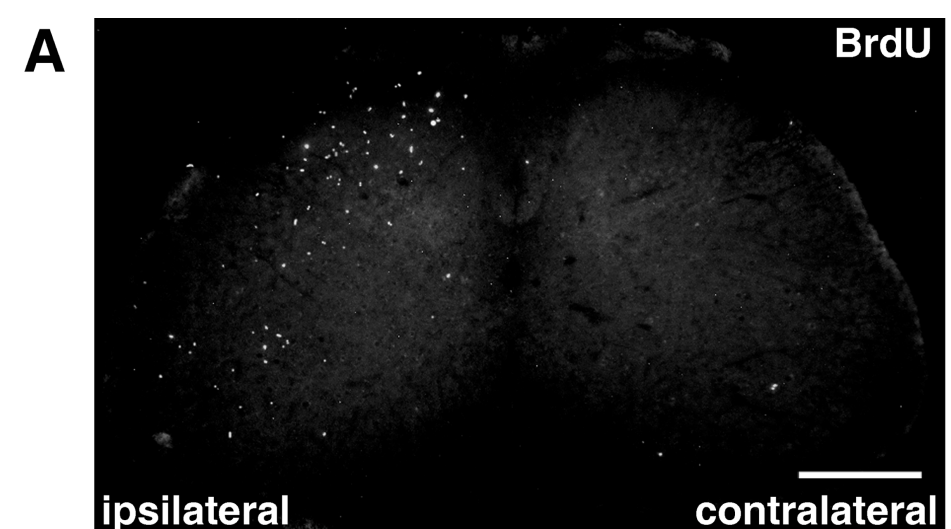

B

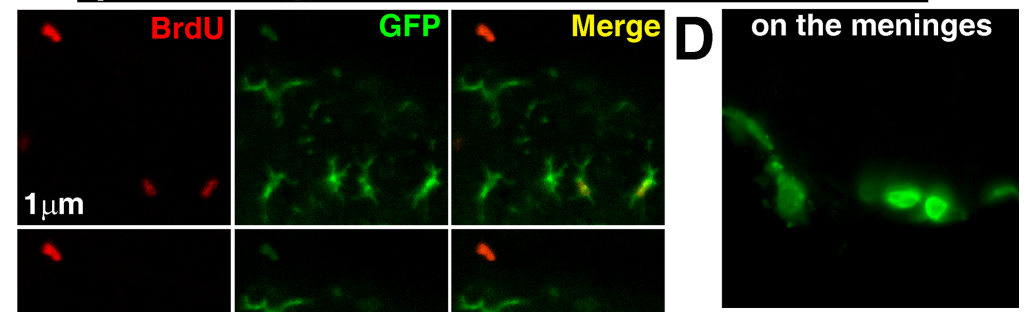

in the parenchyma $-\mathrm{d} 3$

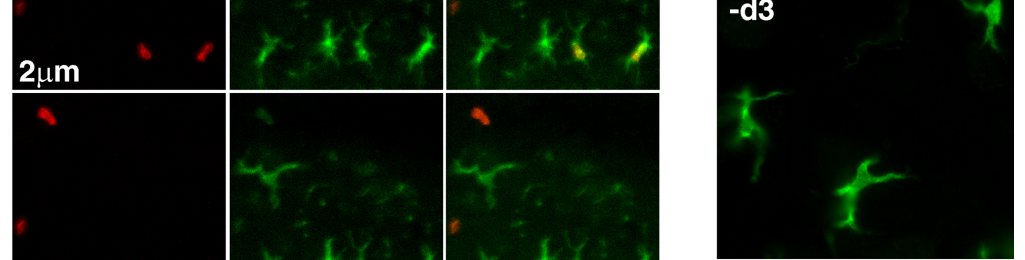

$\mathbf{3} \mu \mathrm{m}$

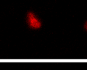

$+$
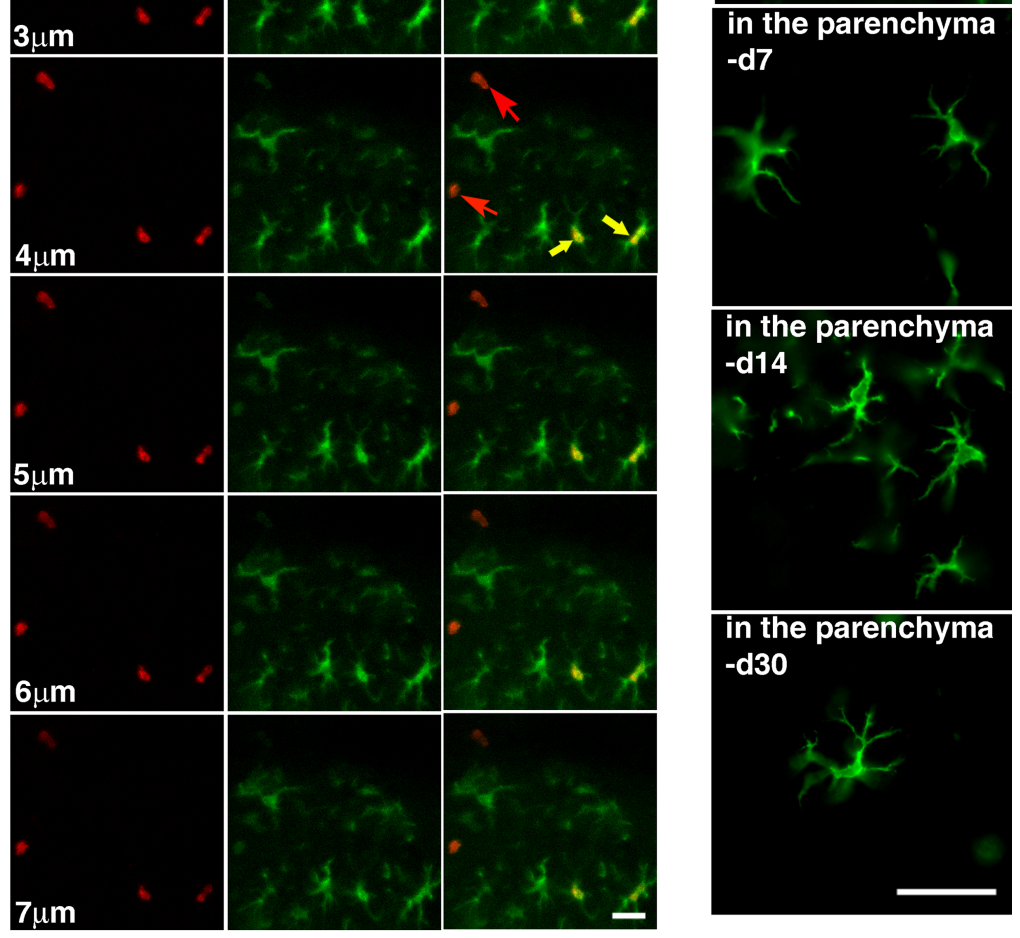

C

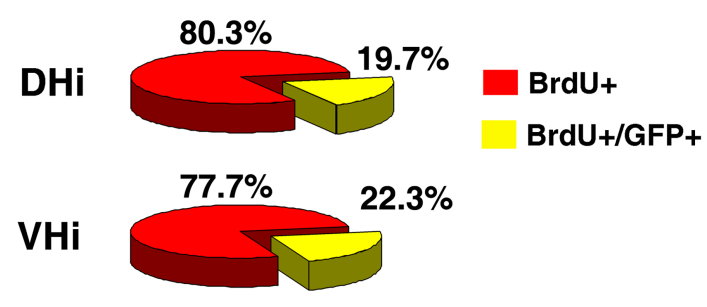


defense. Although the molecular signals and detailed mechanisms responsible for the migration of specific inflammatory cells into the CNS compartment are not completely identified, accumulating evidence suggests that chemokines, in concert with adhesion molecules, are essential for the process (Charo and Ransohoff, 2006). MCP-1, identified originally as monocyte, memory $\mathrm{T}$ lymphocytes and NK cell-specific chemoattractant (Valente et al., 1988; Yoshimura et al., 1989) has been attributed a key role in regulating the infiltration of monocytes during inflammation. MCP-1 knock-out mice exhibited deficient monocyte recruitment in experimental autoimmune encephalomyelitis (Lu et al., 1998; Huang et al., 2001). Entorhinodentate axotomy induces leukocyte infiltration in the denervated hippocampus (Bechmann et al., 2005; Ladeby et al., 2005) in which induced MCP-1 expression by glial cells has been considered as critical in directing leukocytes to sites of axonal injury in the CNS (Babcock et al., 2003). It is interesting to note that, although numerous GFP cells were found in multiple regions of normal brain (the current study; data not shown) (Vallieres and Sawchenko, 2003; Simard and Rivest, 2004), such a process remains rare in the spinal cord of intact mice. However, bone marrow-derived cells infiltrated massively the affected regions ipsilateral to the peripheral nerve damage. This chemotaxis is dependent on MCP-1, because MCP-1 antibody treatment successfully reduced the number of infiltrated cells. This is also dependent on the MCP-1 receptor CCR2, because CCR2-deficient mice no longer exhibited such an accumulation of microglial cells. MCP-1 has the ability to alter expression of tight junctionassociated proteins in endothelial cells of the brain vascular system (Stamatovic et al., 2003; Song and Pachter, 2004), which results in a local and temporary increase of BSCB permeability (Gordh et al., 2006). This may explain why MCP-1 and CCR2 play such a critical role in such a cell influx in the affected spinal cord. We then took advantage of this model to determine the respective contribution of BMderived versus resident microglia in generating chimeric mice and found that both types of cells participate in this process. MCP-1 production by damaged neurons after peripheral nerve injury (Zhang and De Koninck, 2006) may then trigger chemotaxis through its cognate receptor CCR2 expressed in resident and bone marrow-derived microglia.

In response to peripheral nerve injury, spinal glial cells, especially microglia, proliferate (Echeverry et al., 2007). The results from the current study showed that both resident cells
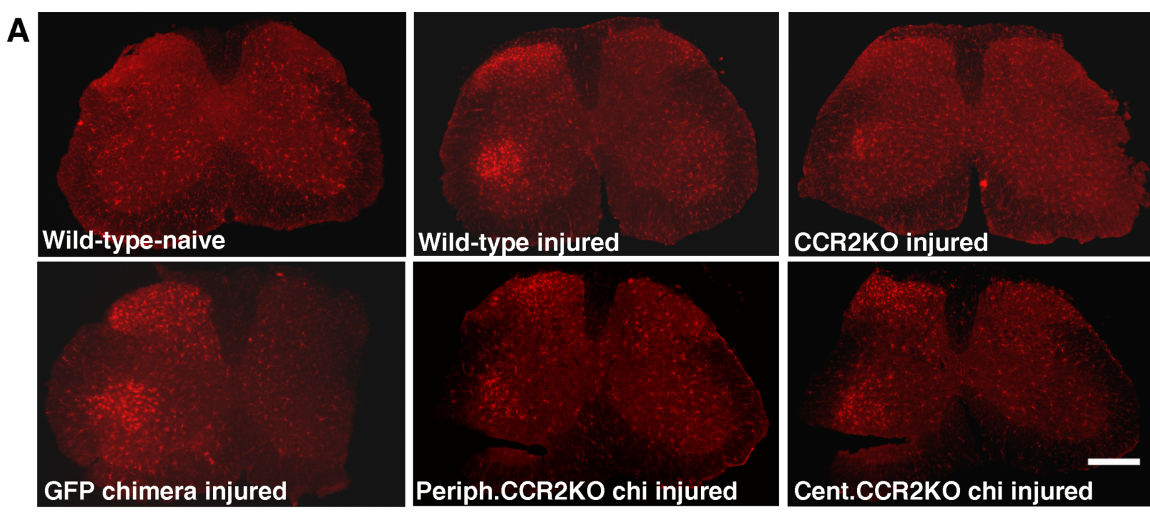

Figure 5. Role of CCR2 in mediating microglial chemotaxis in the spinal cord. $A$, Photomicrographs depicting representative Iba-1-positive cells in mouse $L 5$ regions $14 \mathrm{~d}$ after the sham operation or injury. Partial sciatic nerve ligation induced a striking increase of Iba-1 immunoreactivity (ir) in the ipsilateral side DH/VH in wild-type C57BL/6 mice; this increase in Iba- 1 immunoreactive signal was almost completely abolished in CCR2KO mice, whereas both groups of CCR2KO chimeric mice exhibited partial attenuation when compared with GFP chimeric mice after sciatic nerve ligation (scale bar, $1 \mathrm{~mm}$ ). $\boldsymbol{B}$, Intensity of Iba-1 signal determined as the average pixel intensity on specific regions of interest on $L 5$ sections at $14 \mathrm{~d}$ after injury $(4-6$ sections per mouse, 4 mice per group; data are expressed as mean $\pm \mathrm{SEM} ;{ }^{*} p<0.05,{ }^{* *} p<0.01$, ipsilateral vs contralateral; ${ }^{*} p<0.05$, peripheral/ central CCR2KO DHi vs GFP DHi; \& ${ }_{p}<0.01$, peripheral CCR2KO VHi vs GFP VHi).

Table 1. Quantification of Iba- $1^{+}$cell numbers in the lumber spinal cord of mice with different CCR2 genetic background $14 \mathrm{~d}$ after peripheral nerve injury

\begin{tabular}{|c|c|c|c|c|c|}
\hline \multirow{2}{*}{ 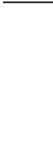 } & \multicolumn{2}{|c|}{ GFP chimeric mice } & \multirow{2}{*}{$\begin{array}{l}\begin{array}{l}\text { Peripheral } \\
\text { CCR2K0 mice }\end{array} \\
\frac{\text { C }}{\text { lba- }^{+}{ }^{+} \text {cells }}\end{array}$} & \multirow{2}{*}{ 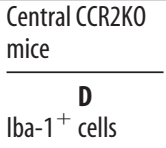 } & \multirow{2}{*}{$\frac{\text { CCR2K0 mice }}{{\text { lba- }{ }^{+} \text {cells }}^{\mathbf{E}}}$} \\
\hline & $\stackrel{\text { A }}{\mathrm{Iba}-1^{+} \text {cells }}$ & $\begin{array}{c}\text { B } \\
\mathrm{GFP}^{+} \text {cells }\end{array}$ & & & \\
\hline $\mathrm{DHi}$ & $59.7 \pm 2.75$ & $16 \pm 4.72$ & $41.65 \pm 2.09^{* *}$ & $42.50 \pm 3.63^{* *}$ & $27.72 \pm 2.1^{* *}$ \\
\hline $\mathrm{DHC}$ & $25.2 \pm 3.83$ & $3 \pm 0.26$ & $22.80 \pm 1.56$ & $20.90 \pm 3.53$ & $23.78 \pm 1.33$ \\
\hline VHi & $56.55 \pm 6.03$ & $21.3 \pm 8.1$ & $33.05 \pm 4.37^{* *}$ & $42.20 \pm 2.42^{*}$ & $26.02 \pm 3.56^{* *}$ \\
\hline VHc & $28.65 \pm 2.95$ & $4 \pm 1.67$ & $26.80 \pm 0.43$ & $25.40 \pm 2.92$ & $26.94 \pm 0.98$ \\
\hline
\end{tabular}

The number of $\mathrm{lba}-1^{+}$microglia was determined in four regions ( $\mathrm{DHi}, \mathrm{DHc}$, $\mathrm{VHi}$, and $\mathrm{VHc}$ ) of the spinal cord ( $4-6$ sections per mouse, 4 mice per group) in four groups (GFP chimeric, peripheral CCR2KO chimeric, central CCR2KO chimeric, and CCR2KO) of mice at $14 \mathrm{~d}$ after injury. Note that, on the ipsilateral side, the number of Iba- $1^{+}$cells was significantly less in mice lacking peripherally, centrally, or totally CCR2 receptor than that in GFP chimeric mice (data are expressed as mean \pm SEM; ${ }^{*} p<0.05,{ }^{* *} p<0.01$, peripheral, central, and total CCR2KO DHi/VHi vs GFP DHi/VHi, respectively).

and blood-derived microglia retain their capacity to divide, in which $20 \%$ of proliferating cells derived from peripheral macrophages. We also observed that infiltrated blood-borne cells can differentiate into highly ramified $\mathrm{Iba}-1^{+}$resident microglia but not in any other types of cells at all tested time points after injury (days 3-30). The potential plasticity of hematopoietic stem cells raised the questions on the trans-lineage differentiation. Several independent groups have provided evidence that bone marrow-derived cells participate in adult neurogenesis and angiogenesis by giving rise to neurons (Mezey et al., 2000; Priller et al., 2001), endothelial cells 
A
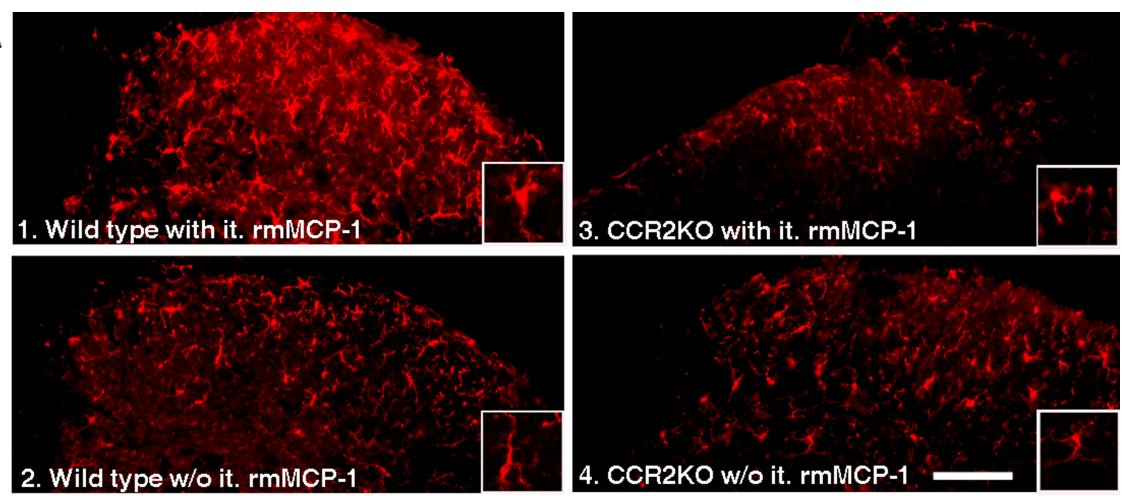

B
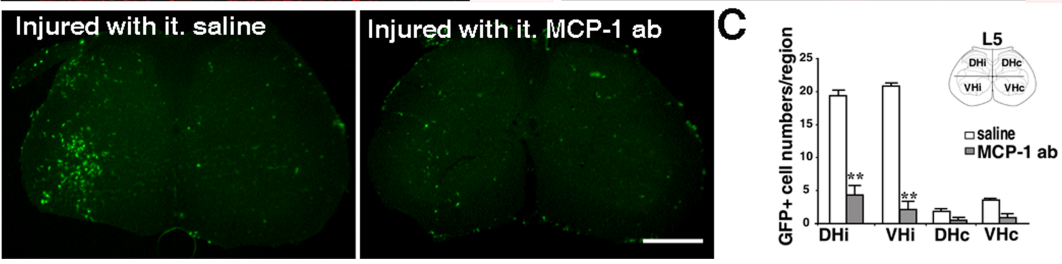

Figure 6. Role of MCP-1 in stimulating resident microglial activation and peripheral macrophage infiltration via its cognate receptor CCR2. A, Intrathecal (it) delivery of rmMCP-1 (3 injections, $2 \mu \mathrm{g}$ in $10 \mu \mathrm{l}$ of saline per injection over $6 \mathrm{~d}$ ) stimulated microglia in the spinal cord of intact wild-type mice as seen by the increase in size of their cell bodies $(\boldsymbol{A} 1)$ when compared with that in mice which did not receive MCP-1 stimulation (A2). These changes were not observed in CCR2-deficient mice: microglial size and shape remained similar in CCR2K0 mice either treated (A3) or not (A4) with MCP-1 (scale bar, $200 \mu \mathrm{m})$. Note the morphological changes highlighted in the insets. $\boldsymbol{B}$, Infiltrated ramified GFP ${ }^{+}$cells were no longer present in the ipsilateral side DH and VH of injured mice treated with MCP-1 antibody (ab). Only few elongated and scattered GFP ${ }^{+}$cells were found in blood vessels, although the number of meningeal GFP ${ }^{+}$cells significantly increased (scale bar, $1 \mathrm{~mm}$ ). C, Quantitative analysis of GFP ${ }^{+}$ cells in the spinal cord of GFP chimeric mice after sciatic nerve injury and MCP-1 neutralization (data are shown as mean \pm SEM; $n=7$ mice/group; ${ }^{* *} p<0.01$, mice treated with MCP-1 antibody vs mice treated with saline). MCP-1 antibody significantly reduced the number of GFP ${ }^{+}$cells within the spinal cord parenchyma.
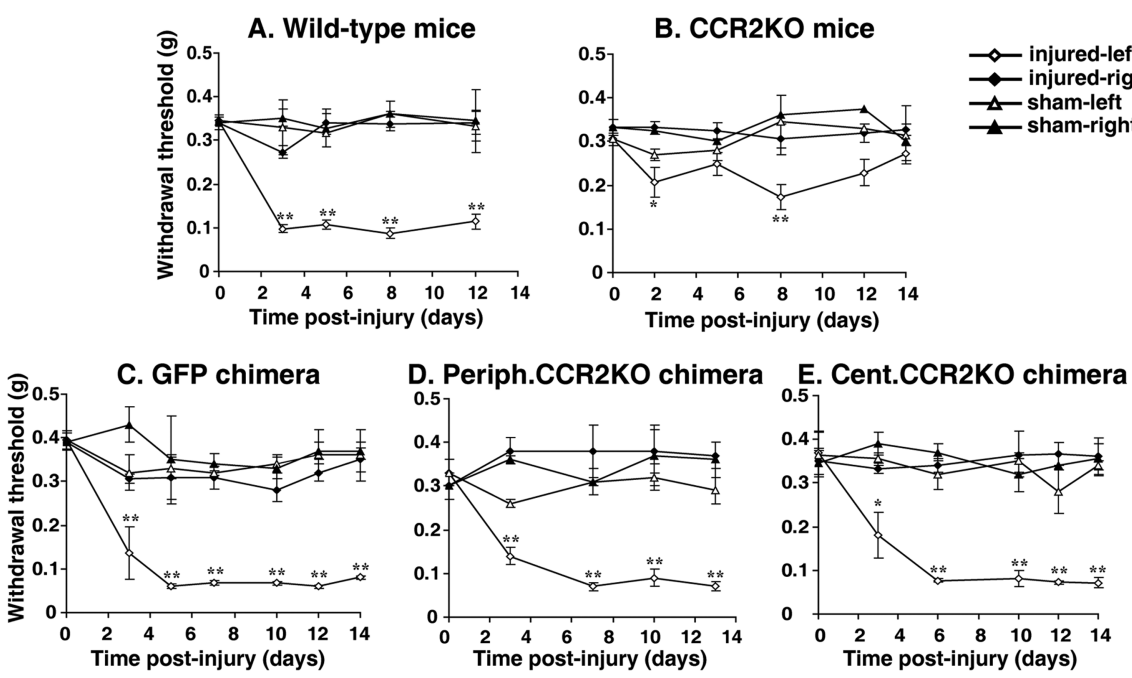

Figure 7. Mechanical allodynia in response to partial sciatic nerve ligation. Injured paw-withdrawal thresholds decreased from baseline $(\sim 0.35 \mathrm{~g}$ ) to below $0.1 \mathrm{~g}$ in all groups, except for CCR2K0 mice. Significant decrease in withdrawal threshold occurred in all chimeric groups, indicating that CCR2 expression in either resident or bone marrow-derived microglia is sufficient to cause mechanical allodynia. Data are shown as mean $\pm \mathrm{SEM}$; ${ }^{*} p<0.05 ;{ }^{* *} p<0.01 ; n=4-6$ mice per group. Baseline data (day 0 ) was obtained by an average of two measurements, $1-2 \mathrm{~d}$ before surgery.

(Bailey et al., 2006), and astrocytes (Kopen et al., 1999). Consistent with some other studies (Simard and Rivest, 2004; Massengale et al., 2005), our findings indicated that bone marrowderived stem cells and their progeny maintain lineage fidelity within the spinal cord parenchyma in the pathology of neuropathic pain induced by peripheral nerve injury. The discrep-

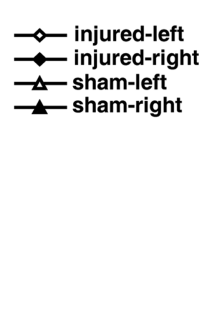

ancy may be explained by technical problems (specificity of cellular markers and sensitivity of histochemical methods) but most likely the difference may result from anatomical distributions, because the BM-derived cells exhibiting the characteristic morphology of cerebellar Purkinje neurons has been observed more frequently (Priller et al., 2001; Wright et al., 2001) and also from different pathophysiological conditions.

The contribution of glia and glianeuron communication in enhancing nociceptive transmission has been well documented. Every animal model of nerve injury-induced exaggerated pain is associated with the activation of glia within the pain-responsive regions of the spinal cord (Tsuda et al., 2005). Such exaggerated pain states are mediated by glial activation, because they are blocked by drugs (e.g., fluorocitrate and minocycline) that block glial activation (Milligan et al., 2003; Raghavendra et al., 2003), by selective proinflammatory cytokine antagonists (Sweitzer et al., 2001), and by disrupting proinflammatory cytokine signaling pathway (Sweitzer et al., 2004). We revealed in this study that nerve injury induced microglial activation comprises the activation of preexisting resident microglia, as well as the recruitment of BM-derived peripheral macrophages. Of important impact is that both populations are involved in the central component of sensitization to enhance spinal neuronal excitability by dynamic glial modulators, such as ATP and BDNF (Tsuda et al., 2003; Coull et al., 2005). Either resident microglia (central sensitization) or peripheral macrophages (central sensitization by infiltration into the spinal cord and peripheral sensitization by their activity at the injured site) is sufficient to cause the neuropathic pain. The fact that Iba-1 staining was significantly reduced in both central and peripheral CCR2KO chimeric mice (compared with GFP chimeric mice) while neuropathic pain behavior remained identical in all three lines of mice suggest that there may be a floor effect on the behavior, i.e., that the amount of microglia activation in the wild type is supramaximal, in other words, more than enough to produce a full effect. Rutkowski et al. (2000) demonstrated that mechanical allodynia was not altered by either deactivation of macrophages with CNI-1493 or by depletion of circulating macrophages using lisosome-encapsulated clodronate before peripheral nerve injury. They concluded that macrophages have limited role in generation of nerve injuryinduced mechanical allodynia. It was also reported that mac- 
rophage depletion by intravenous injection of liposomeencapsulated clodronate reduced the number of macrophages in the injured nerve and alleviated slightly thermal hyperalgesia (Liu et al., 2000). The discrepancy with our results may stem from differences in the behavioral outcomes measured (mechanical allodynia vs thermal hyperalgesia). In light of our current findings, we suggested that peripheral macrophages have significant contribution not only in peripheral but also in central sensitization. However, blockade of only circulating macrophages is not enough to attenuate hypersensitivity, because the involvement of spinal cord resident microglia in the central component is not negligible.

Our results not only implicated MCP-1 as a necessary mediator for spinal microglial activation, they point to the chemokine as being a major player for the development of mechanical allodynia. These data are consistent with another study showing an essential role of CCR2 in mediating neuropathic pain in mice (Abbadie et al., 2003). We further revealed the critical role of CCR2 in peripheral macrophages and resident microglia through neuron-to-macrophages and neuronto-microglia interaction in the genesis of ongoing neuropathic pain. In addition, MCP-1 was reported to depolarize sensory neurons after chronic compression of the dorsal root ganglion (White et al., 2005), which implicates a direct neuron-toneuron interaction of the ligand with its receptor. Some other mediators for neuron-to-glia communication that could lead to glial activation and consequent enhancement of pain have been suggested. ATP activates glia and the release of proinflammatory cytokines (Hide et al., 2000; Shigemoto-Mogami et al., 2001). Mice lacking either purinergic $\mathrm{P}_{2} \mathrm{X}_{4}$ or $\mathrm{P} 2 \mathrm{X}_{7}$ receptors show an impaired ability to develop neuropathic pain (Tsuda et al., 2003; Chessell et al., 2005). The chemokine fractalkine has also been suggested to contribute to the hypersensitivity evoked by nerve injury through microglial activation (Verge et al., 2004). Mice that bear a mutation in the gene encoding toll-like receptor 4 (TLR4) have a reduced microglial activation and do not develop thermal and mechanical allodynia after peripheral nerve injury (Tanga et al., 2004). Heat shock protein 27 was proposed to be the potential endogenous ligand for TLR4 (Costigan et al., 1998). Although considerable redundancy may exist, microglial activation and recruitment through MCP-1/CCR2 seem a critical component for the pathogenesis of neuropathic pain.

The ability of macrophages to infiltrate and differentiate into fully functional microglia in the CNS parenchyma opens the door for new therapeutic strategies to treat neuropathic pain. Indeed, these cells are innately and specifically attracted to injured and diseased regions and may thus be used as effective and selective vehicles to deliver molecules that prevent neurodegeneration (Scholz et al., 2005), eliminate toxic proteins or pronociceptive signaling molecules (Shubayev and Myers, 2002; Coull et al., 2005), or deliver anti-inflammatory agents (Ledeboer et al., 2007). BM-derived cells will be able to follow the chemoattracting gradient provided by the distressed neurons (e.g., MCP-1) early after injury and specifically in the affected region and deliver the necessary molecules to limit microgliosis and neuronal hypersensitivity. A similar approach can be envisaged to treat neurodegenerative diseases, such as Alzheimer's disease (Simard et al., 2006), amyotrophic lateral sclerosis (Solomon et al., 2006), prion disease (Priller et al., 2006), and multiple sclerosis (Raivich and Banati, 2004) in which BM-derived cells massively infiltrate the affected regions.

\section{References}

Abbadie C, Lindia JA, Cumiskey AM, Peterson LB, Mudgett JS, Bayne EK, DeMartino JA, MacIntyre DE, Forrest MJ (2003) Impaired neuropathic pain responses in mice lacking the chemokine receptor CCR2. Proc Natl Acad Sci USA 100:7947-7952.

Ambrosini E, Aloisi F (2004) Chemokines and glial cells: a complex network in the central nervous system. Neurochem Res 29:1017-1038.

Babcock AA, Kuziel WA, Rivest S, Owens T (2003) Chemokine expression by glial cells directs leukocytes to sites of axonal injury in the CNS. J Neurosci 23:7922-7930.

Bailey AS, Willenbring H, Jiang S, Anderson DA, Schroeder DA, Wong MH, Grompe M, Fleming WH (2006) Myeloid lineage progenitors give rise to vascular endothelium. Proc Natl Acad Sci USA 103:13156-13161.

Baron R (2006) Mechanisms of disease: neuropathic pain—a clinical perspective. Nat Clin Pract Neurol 2:95-106.

Bechmann I, Goldmann J, Kovac AD, Kwidzinski E, Simburger E, Naftolin F, Dirnagl U, Nitsch R, Priller J (2005) Circulating monocytic cells infiltrate layers of anterograde axonal degeneration where they transform into microglia. FASEB J 19:647-649.

Campbell JN, Meyer RA (2006) Mechanisms of neuropathic pain. Neuron 52:77-92.

Chaplan SR, Bach FW, Pogrel JW, Chung JM, Yaksh TL (1994) Quantitative assessment of tactile allodynia in the rat paw. J Neurosci Methods 53:55-63.

Charo IF, Ransohoff RM (2006) The many roles of chemokines and chemokine receptors in inflammation. N Engl J Med 354:610-621.

Chessell IP, Hatcher JP, Bountra C, Michel AD, Hughes JP, Green P, Egerton J, Murfin M, Richardson J, Peck WL, Grahames CB, Casula MA, Yiangou Y, Birch R, Anand P, Buell GN (2005) Disruption of the P2X7 purinoceptor gene abolishes chronic inflammatory and neuropathic pain. Pain 114:386-396.

Colburn RW, Rickman AJ, DeLeo JA (1999) The effect of site and type of nerve injury on spinal glial activation and neuropathic pain behavior. Exp Neurol 157:289-304.

Costigan M, Mannion RJ, Kendall G, Lewis SE, Campagna JA, Coggeshall RE, Meridith-Middleton J, Tate S, Woolf CJ (1998) Heat shock protein 27: developmental regulation and expression after peripheral nerve injury. J Neurosci 18:5891-5900.

Coull JA, Beggs S, Boudreau D, Boivin D, Tsuda M, Inoue K, Gravel C, Salter MW, De Koninck Y (2005) BDNF from microglia causes the shift in neuronal anion gradient underlying neuropathic pain. Nature 438:1017-1021.

Coyle DE (1998) Partial peripheral nerve injury leads to activation of astroglia and microglia which parallels the development of allodynic behavior. Glia 23:75-83.

Denker SP, Ji S, Dingman A, Lee SY, Derugin N, Wendland MF, Vexler ZS (2007) Macrophages are comprised of resident brain microglia not infiltrating peripheral monocytes acutely after neonatal stroke. J Neurochem 100:893-904.

Echeverry S, Shi XQ, Zhang J (2007) Characterization of cell proliferation in rat spinal cord following peripheral nerve injury and the relationship with neuropathic pain. Pain, in press.

Flugel A, Hager G, Horvat A, Spitzer C, Singer GM, Graeber MB, Kreutzberg GW, Schwaiger FW (2001) Neuronal MCP-1 expression in response to remote nerve injury. J Cereb Blood Flow Metab 21:69-76.

Fu KY, Light AR, Matsushima GK, Maixner W (1999) Microglial reactions after subcutaneous formalin injection into the rat hind paw. Brain Res 825:59-67.

Furuya T, Tanaka R, Urabe T, Hayakawa J, Migita M, Shimada T, Mizuno Y, Mochizuki H (2003) Establishment of modified chimeric mice using GFP bone marrow as a model for neurological disorders. NeuroReport 14:629-631.

Gordh T, Chu H, Sharma HS (2006) Spinal nerve lesion alters blood-spinal cord barrier function and activates astrocytes in the rat. Pain 124:211-221

Hide I, Tanaka M, Inoue A, Nakajima K, Kohsaka S, Inoue K, Nakata Y (2000) Extracellular ATP triggers tumor necrosis factor-alpha release from rat microglia. J Neurochem 75:965-972.

Horky LL, Galimi F, Gage FH, Horner PJ (2006) Fate of endogenous stem/ progenitor cells following spinal cord injury. J Comp Neurol 498:525-538. 
Huang DR, Wang J, Kivisakk P, Rollins BJ, Ransohoff RM (2001) Absence of monocyte chemoattractant protein 1 in mice leads to decreased local macrophage recruitment and antigen-specific $T$ helper cell type $1 \mathrm{im}$ mune response in experimental autoimmune encephalomyelitis. J Exp Med 193:713-726.

Kopen GC, Prockop DJ, Phinney DG (1999) Marrow stromal cells migrate throughout forebrain and cerebellum, and they differentiate into astrocytes after injection into neonatal mouse brains. Proc Natl Acad Sci USA 96:10711-10716.

Kreutzberg GW (1996) Microglia: a sensor for pathological events in the CNS. Trends Neurosci 19:312-318.

Ladeby R, Wirenfeldt M, Dalmau I, Gregersen R, Garcia-Ovejero D, Babcock A, Owens T, Finsen B (2005) Proliferating resident microglia express the stem cell antigen CD34 in response to acute neural injury. Glia 50:121-131.

Lawson LJ, Perry VH, Gordon S (1992) Turnover of resident microglia in the normal adult mouse brain. Neuroscience 48:405-415.

Ledeboer A, Jekich BM, Sloane EM, Mahoney JH, Langer SJ, Milligan ED, Martin D, Maier SF, Johnson KW, Leinwand LA, Chavez RA, Watkins LR (2007) Intrathecal interleukin-10 gene therapy attenuates paclitaxel-induced mechanical allodynia and proinflammatory cytokine expression in dorsal root ganglia in rats. Brain Behav Immun 21:686-698.

Leonard EJ, Skeel A, Yoshimura T (1991) Biological aspects of monocyte chemoattractant protein-1 (MCP-1). Adv Exp Med Biol 305:57-64.

Liu T, van Rooijen N, Tracey DJ (2000) Depletion of macrophages reduces axonal degeneration and hyperalgesia following nerve injury. Pain 86:25-32.

Lu B, Rutledge BJ, Gu L, Fiorillo J, Lukacs NW, Kunkel SL, North R, Gerard C, Rollins BJ (1998) Abnormalities in monocyte recruitment and cytokine expression in monocyte chemoattractant protein 1-deficient mice. J Exp Med 187:601-608.

Malmberg AB, Basbaum AI (1998) Partial sciatic nerve injury in the mouse as a model of neuropathic pain: behavioral and neuroanatomical correlates. Pain 76:215-222.

Marchand F, Perretti M, McMahon SB (2005) Role of the immune system in chronic pain. Nat Rev Neurosci 6:521-532.

Marx J (2004) Pain research. Prolonging the agony. Science 305:326-329.

Massengale M, Wagers AJ, Vogel H, Weissman IL (2005) Hematopoietic cells maintain hematopoietic fates upon entering the brain. J Exp Med 201:1579-1589.

Mezey E, Chandross KJ, Harta G, Maki RA, McKercher SR (2000) Turning blood into brain: cells bearing neuronal antigens generated in vivo from bone marrow. Science 290:1779-1782.

Milligan ED, Twining C, Chacur M, Biedenkapp J, O’Connor K, Poole S, Tracey K, Martin D, Maier SF, Watkins LR (2003) Spinal glia and proinflammatory cytokines mediate mirror-image neuropathic pain in rats. J Neurosci 23:1026-1040.

Mogil JS, Wilson SG, Bon K, Lee SE, Chung K, Raber P, Pieper JO, Hain HS, Belknap JK, Hubert L, Elmer GI, Chung JM, Devor M (1999) Heritability of nociception I: responses of 11 inbred mouse strains on 12 measures of nociception. Pain 80:67-82.

Moser B, Wolf M, Walz A, Loetscher P (2004) Chemokines: multiple levels of leukocyte migration control. Trends Immunol 25:75-84.

Priller J, Flugel A, Wehner T, Boentert M, Haas CA, Prinz M, Fernandez-Klett F, Prass K, Bechmann I, de Boer BA, Frotscher M, Kreutzberg GW, Persons DA, Dirnagl U (2001) Targeting gene-modified hematopoietic cells to the central nervous system: use of green fluorescent protein uncovers microglial engraftment. Nat Med 7:1356-1361.

Priller J, Prinz M, Heikenwalder M, Zeller N, Schwarz P, Heppner FL, Aguzzi A (2006) Early and rapid engraftment of bone marrow-derived microglia in scrapie. J Neurosci 26:11753-11762.

Raghavendra V, Tanga F, DeLeo JA (2003) Inhibition of microglial activation attenuates the development but not existing hypersensitivity in a rat model of neuropathy. J Pharmacol Exp Ther 306:624-630.

Raivich G, Banati R (2004) Brain microglia and blood-derived macrophages: molecular profiles and functional roles in multiple sclerosis and animal models of autoimmune demyelinating disease. Brain Res Brain Res Rev 46:261-281.

Ransohoff RM, Tani M (1998) Do chemokines mediate leukocyte recruitment in post-traumatic CNS inflammation? Trends Neurosci 21:154-159.

Rebenko-Moll NM, Liu L, Cardona A, Ransohoff RM (2006) Chemokines, mononuclear cells and the nervous system: heaven (or hell) is in the details. Curr Opin Immunol 18:683-689.

Rot A, von Andrian UH (2004) Chemokines in innate and adaptive host defense: basic chemokinese grammar for immune cells. Annu Rev Immunol 22:891-928.

Rutkowski MD, Pahl JL, Sweitzer S, van Rooijen N, Deleo JA (2000) Limited role of macrophages in generation of nerve injury-induced mechanical allodynia. Physiol Behav 71:225-235.

Scholz J, Broom DC, Youn DH, Mills CD, Kohno T, Suter MR, Moore KA, Decosterd I, Coggeshall RE, Woolf CJ (2005) Blocking caspase activity prevents transsynaptic neuronal apoptosis and the loss of inhibition in lamina II of the dorsal horn after peripheral nerve injury. J Neurosci 25:7317-7323.

Schreiber RC, Krivacic K, Kirby B, Vaccariello SA, Wei T, Ransohoff RM, Zigmond RE (2001) Monocyte chemoattractant protein (MCP)-1 is rapidly expressed by sympathetic ganglion neurons following axonal injury. NeuroReport 12:601-606.

Seltzer Z, Dubner R, Shir Y (1990) A novel behavioral model of neuropathic pain disorders produced in rats by partial sciatic nerve injury. Pain 43:205-218.

Shigemoto-Mogami Y, Koizumi S, Tsuda M, Ohsawa K, Kohsaka S, Inoue K (2001) Mechanisms underlying extracellular ATP-evoked interleukin-6 release in mouse microglial cell line, MG-5. J Neurochem 78:1339-1349.

Shubayev VI, Myers RR (2002) Anterograde TNF alpha transport from rat dorsal root ganglion to spinal cord and injured sciatic nerve. Neurosci Lett 320:99-101.

Simard AR, Rivest S (2004) Bone marrow stem cells have the ability to populate the entire central nervous system into fully differentiated parenchymal microglia. FASEB J 18:998-1000.

Simard AR, Soulet D, Gowing G, Julien JP, Rivest S (2006) Bone marrowderived microglia play a critical role in restricting senile plaque formation in Alzheimer's disease. Neuron 49:489-502.

Solomon JN, Lewis CA, Ajami B, Corbel SY, Rossi FM, Krieger C (2006) Origin and distribution of bone marrow-derived cells in the central nervous system in a mouse model of amyotrophic lateral sclerosis. Glia 53:744-753.

Song L, Pachter JS (2004) Monocyte chemoattractant protein-1 alters expression of tight junction-associated proteins in brain microvascular endothelial cells. Microvasc Res 67:78-89.

Stamatovic SM, Keep RF, Kunkel SL, Andjelkovic AV (2003) Potential role of MCP-1 in endothelial cell tight junction "opening:" signaling via Rho and Rho kinase. J Cell Sci 116:4615-4628.

Streit WJ, Graeber MB, Kreutzberg GW (1989) Expression of Ia antigen on perivascular and microglial cells after sublethal and lethal motor neuron injury. Exp Neurol 105:115-126.

Sweitzer S, Martin D, DeLeo JA (2001) Intrathecal interleukin-1 receptor antagonist in combination with soluble tumor necrosis factor receptor exhibits an anti-allodynic action in a rat model of neuropathic pain. Neuroscience 103:529-539.

Sweitzer SM, Hickey WF, Rutkowski MD, Pahl JL, DeLeo JA (2002) Focal peripheral nerve injury induces leukocyte trafficking into the central nervous system: potential relationship to neuropathic pain. Pain 100:163-170.

Sweitzer SM, Medicherla S, Almirez R, Dugar S, Chakravarty S, Shumilla JA, Yeomans DC, Protter AA (2004) Antinociceptive action of a p38alpha MAPK inhibitor, SD-282, in a diabetic neuropathy model. Pain 109:409-419.

Tanaka T, Minami M, Nakagawa T, Satoh M (2004) Enhanced production of monocyte chemoattractant protein-1 in the dorsal root ganglia in a rat model of neuropathic pain: possible involvement in the development of neuropathic pain. Neurosci Res 48:463-469.

Tanga FY, Raghavendra V, DeLeo JA (2004) Quantitative real-time RTPCR assessment of spinal microglial and astrocytic activation markers in a rat model of neuropathic pain. Neurochem Int 45:397-407.

Tsuda M, Shigemoto-Mogami Y, Koizumi S, Mizokoshi A, Kohsaka S, Salter MW, Inoue K (2003) P2X4 receptors induced in spinal microglia gate tactile allodynia after nerve injury. Nature 424:778-783.

Tsuda M, Inoue K, Salter MW (2005) Neuropathic pain and spinal microglia: a big problem from molecules in "small" glia. Trends Neurosci 28:101-107.

Valente AJ, Graves DT, Vialle-Valentin CE, Delgado R, Schwartz CJ (1988) 
Purification of a monocyte chemotactic factor secreted by nonhuman primate vascular cells in culture. Biochemistry 27:4162-4168.

Vallieres L, Sawchenko PE (2003) Bone marrow-derived cells that populate the adult mouse brain preserve their hematopoietic identity. J Neurosci 23:5197-5207.

Verge GM, Milligan ED, Maier SF, Watkins LR, Naeve GS, Foster AC (2004) Fractalkine (CX3CL1) and fractalkine receptor (CX3CR1) distribution in spinal cord and dorsal root ganglia under basal and neuropathic pain conditions. Eur J Neurosci 20:1150-1160.

White FA, Sun J, Waters SM, Ma C, Ren D, Ripsch M, Steflik J, Cortright DN, Lamotte RH, Miller RJ (2005) Excitatory monocyte chemoattractan protein-1 signaling is up-regulated in sensory neurons after chronic compression of the dorsal root ganglion. Proc Natl Acad Sci USA 102:14092-14097.
Wright DE, Wagers AJ, Gulati AP, Johnson FL, Weissman IL (2001) Physiological migration of hematopoietic stem and progenitor cells. Science 294:1933-1936.

Yoshimura T, Robinson EA, Appella E, Matsushima K, Showalter SD, Skeel A, Leonard EJ (1989) Three forms of monocyte-derived neutrophil chemotactic factor (MDNCF) distinguished by different lengths of the amino-terminal sequence. Mol Immunol 26:87-93.

Zhang J, De Koninck Y (2006) Spatial and temporal relationship between monocyte chemoattractant protein-1 expression and spinal glial activation following peripheral nerve injury. J Neurochem 97:772-783.

Zhang J, Hoffert C, Vu HK, Groblewski T, Ahmad S, O’Donnell D (2003) Induction of $\mathrm{CB} 2$ receptor expression in the rat spinal cord of neuropathic but not inflammatory chronic pain models. Eur J Neurosci 17: $2750-2754$. 